\title{
Molecular Defect of Spectrin in the Family of a Child with Congenital Hemolytic Poikilocytic Anemia
}

\author{
D. DHERMY, M. C. LECOMTE, M. GARBARZ, C. FEO, H. GAUTERO, O. BOURNIER, \\ C. GALAND, A. HERRERA, F. GRETILLAT, AND P. BOIVIN \\ Unité de Recherches d'Enzymologie des Cellules Sanguines (INSERUM U160, CNRS ERA 573), Hôpital \\ Beaujon F-92118 Clichy Cedex [D.D., M.C.L., M.G., H.G., O.B., C.G., A.H., P.B.] Institut de Pathologie \\ Cellulaire (INSERM U48), Hôpital de Bicêtre, F-94270 le Kremlin-Bicetre [C.F.], and Service de Pédiatrie, Dr. \\ Herrault, Hôpital Hêrold, F-75935 Paris Cedex 19, France [F.G.]
}

\begin{abstract}
Summary
We present the study of a black family in which the proband suffered from a severe neonatal hemolytic anemia with poikilocytosis. Both the parents, sister's, and brother's proband were clinically normal. The presence of poikilocytes in proband led to a search for a red cell membrane skeleton defect. Owing to recent improvements in the erythrocyte membrane knowledge, it is now possible to approach the diagnosis by means of biochemical evaluation of both parents, even if they are asymptomatic. So, the first time discovery of a spectrin self-association defect in both parents allowed us to suspect double inheritance of this abnormality in the proband. A complete morphological and biochemical evaluation of the family allowed us to propound the diagnosis of heterozygous type I hereditary elliptocytosis (HE) for both parents and the sister and the diagnosis of homozygous type I HE for the proband owing to the following reasons: slight ovalocytosis was present in both parents and the sister; cell deformability ektacytometric studies gave the same profiles of curve as those observed in patients with HE. Defective spectrin dimer self-association found in both parents was also observed in the sister and proband, associated with the same abnormal spectrin digest pattern, namely a decrease in the amount of a $\mathbf{8 0 , 0 0 0}$-dalton peptide and a corresponding increase in a $\mathbf{7 4 , 0 0 0 -}$ dalton peptide. However, clinical presentation of the proband was consistent either with hereditary pyropoikilocytosis or homozygous hereditary elliptocytosis; erythrocyte thermal sensitivity studies in the proband could not be conclusive because of the presence of transfused cells. Both these diagnoses are discussed in detail. Other modifications of spectrin tryptic patterns were detectable and were not related to the functional defect of spectrin since the proband's normal brother appeared homozygous for these modifications.
\end{abstract}

\section{Abbreviations}

HPP, hereditary pyropoikilocytosis

HE, hereditary elliptocytosis

PMSF, phenylmethylsulfonyl fluoride

SDS, sodium dodecyl sulfate

BME, $\beta$-mercaptoethanol

Received November 3, 1983; accepted February 6, 1984.

Address reprint requests to Dr. Didier Dhermy, INSERM U160, Hôpital Beaujon, Abrami 2e 92118 Clichy Cedex, France.

This work was supported by Institut National de la Santé et de la Recherche Médicale Grant PRC 129044 and Ministère de la Recherche et de I'Industrie 82.L. 1115
PBS, phosphate-buffered saline

EI, ektacytometric index

NDGE, nondenaturing gel electrophoresis

TPCK, L-1-tosylamidophenylethyl chloromethyl ketone

The human red cell contains on the internal face of its lipid bilayer a two-dimensional proteinaceous meshwork named membrane skeleton which is the major determinant of membrane shape and stability (7). The skeleton is mainly composed of spectrin, actin, protein 4.1 , and ankyrin. Spectrin is basically a heterodimer composed of an $\alpha$ and $\beta$ chain (molecular weights, 240,000 and 220,000 daltons, respectively). Each $\alpha$ and $\beta$ subunit was resolved into several peptide domains by restricted tryptic cleavage. These domains were named $\alpha \mathrm{I}$ to $\alpha \mathrm{V}$ and $\beta \mathrm{I}$ to $\beta \mathrm{IV}$ (36). The spectrin dimer associates head to head to form a tetramer which represents the putative basic unit of the membrane skeleton. Spectrin tetramers are cross-linked by actin and protein 4.1 to form a meshwork (39). Ankyrin fastens the skeleton to the lipid bilayer by means of its interactions between spectrin $\beta$ chain and the integral membrane protein band 3 (3). Liu and Palek (24) have shown that stability of the normal membrane skeleton is related to its high content in the tetrameric form of spectrin. If tetramer is experimentally induced to transform into dimer in the membrane, the mechanical stability of the skeleton decreases.

Several cases of hemolytic neonatal anemia with poikilocytosis and bizarre red cell morphology have been related to inherited defects of the membrane skeleton: a complete deficit of protein 4.1 has been reported in three children $(11,37)$. Their parents were related and showed elliptocytosis and partial deficit of protein 4.1. Agre et al. (1) have reported two unrelated families with a form of hemolytic poikilocytic anemia. The four affected patients presented a reduction in the number of high affinity membrane-binding sites for ankyrin. HPP is characterized by an unusual thermal sensitivity of erythrocytes which fragment at $43-46^{\circ} \mathrm{C}$ instead of $49^{\circ} \mathrm{C}$ in normal subjects (42). It is now obvious that this disease is related to defective spectrin dimer self-association $(8,26)$. The same functional defect of spectrin has been also found in several cases of HE, termed type I HE (6, 25). More recently, Evans et al. (10) have reported a family in which three children had homozygous HE with severe poikilocytic anemia. A marked defective spectrin dimer self-association was found in all three patients. Their unrelated parents displayed mild $\mathrm{HE}$ and a lesser but significant defect in spectrin selfassociation. Lawler et al. (19), Knowles et al. (17), and Liu et al. 
(23) described alterations in the trypsin-resistant domains of spectrin in HPP and in few cases of type I HE. These alterations correlated with the defective self-association of spectrin dimer.

We studied a black family in which the proband suffered from a severe neonatal hemolytic anemia with poikilocytosis. Both parents', the sister's, and brother's proband were clinically normal. Morphology and deformability of the red cells and spectrin self-association studies performed in this family led us to discuss the diagnosis of homozygous type I HE in the proband. In addition, the functional defect of spectrin appeared to be related to an abnormal limited tryptic digest pattern of the spectrin molecule. The observation of this family illustrates the contribution of biochemical studies to the diagnosis of poikilocytic hemolytic anemia in children and to the identification of asymptomatic carriers.

\section{CASE REPORT}

The family we studied is of Malian extraction. The clinical report of the proband Mam. T., a male child, has been extensively described (14). Briefly, Mam. T. was born in October 1981 after 38 weeks of a normal pregnancy. He was the third child alive (a boy was stillborn after 36 weeks of pregnancy without apparent etiology). Delivery was normal, no congenital defects were apparent, but the amniotic fluid was colored. At $6 \mathrm{~h}$, icterus and hepatomegaly were noted. Hemoglobinuria was present and bilirubinemia was $240 \mathrm{mmol} / \mathrm{liter}$. Hemoglobin was $8.3 \mathrm{~g} / \mathrm{dl}$, red blood cell count was $3.5 \times 10^{12} /$ liter, hematocrit was $23 \%$, reticulocyte count was $6 \times 10^{11} /$ liter, and erythroblast count was $5 \times 10^{10}$ /iter. On blood smears, anisochromy, anisocytosis, and poikilocytosis were noted. The blood group of both the mother and the child was $\mathrm{O} \mathrm{Rh}(+)$. The Coombs test was negative. Red cell enzymes (glucose-6-phosphate dehydrogenase and pyruvate kinase) were normal. Bone marrow studies showed erythroblastic hyperplasia without maturation abnormalities. However, marked iron overload was noticed in the reticuloendothelial cells. Serological tests of infectious diseases were negative (rubella, herpes, toxoplasmosis, Epstein-Barr virus). Two exchange transfusions were required at 16 and $26 \mathrm{~h}$ because of bilirubin level greater than $550 \mathrm{nmol} /$ liter but he relapsed into anemia and was transfused again at days 6, 14, and 26. During the subsequent months, the child continued to have a severe hemolytic anemia and until today, he requires blood transfusions every month. Nevertheless, growth and development have been within normal limits. Hemoglobin chain synthesis was normal but a heterozygous HbS state was depicted. HLA typing of the child and both parents was not consistent with a false paternity and showed that the parents were not related.

The parents (mother Men. T. and father Abd. T.), sister Rab. T., and brother Han. T. have no signifiant medical history and nothing suggested the possibility of a congenital hemolytic disease. The last sister, Mag. T., was born prematurely and died 3 months later because of respiratory failure and septicemia. A sample of blood, collected on the 3rd day of her life, was available for red blood morphological and deformability studies. She never experienced hemolytic anemia. Red cell enzymes (glucose-6phosphate dehydrogenase and pyruvate kinase) were normal in both parents and hemoglobin studies revealed heterozygous $\mathrm{HbS}$ $\alpha$-thalassemia in the father and were normal in the mother and brother; Rab. T. was found to be heterozygous HbS. Serum iron was in the range of normal values in the mother $(11 \mu \mathrm{mol} / \mathrm{liter}$ with a total iron-binding capacity of $61 \mu \mathrm{mol} / \mathrm{liter})$.

\section{MATERIALS AND METHODS}

Materials. $\beta \mathrm{ME}$, glutaraldehyde, EDTA, Tris, glycerol, sucrose for density gradient studies, and TPCK-trypsin (3.5 units/mg) were from Merck (Darmstadt, G. F. R.). PMSF and diisopropyl fluorophosphate were from Sigma (St Louis, MO). All materials used for sodium dodecyl sulfate-polyacrylamide gel electrophoresis were from Bio-Rad Laboratories (Richmond, CA). Samples of venous blood, obtained from the different members of the family were anticoagulated with heparin and used within $24 \mathrm{~h}$. Studies performed in the proband were done 7 weeks after a transfusion.

Methods. Routine hematologic determinations. Results were obtained with a Coulter Counter Model S. Reticulocytes counts were made after new methylene blue staining.

Morphological studies. Erythrocytes were examined on dried smears stained with May-Grünwald-Geimsa and on wet smears; for this latter purpose, fresh blood samples were immediately fixed in $5 \mathrm{mM} \mathrm{NaPO}_{4}, 150 \mathrm{mM} \mathrm{NaCl}, \mathrm{pH} 7.4$ (PBS) with $1 \%$ glutaraldehyde and examined by light phase contrast microscopy.

Red cell thermal sensitivity study. Control and patient erythrocyte thermal sensitivity was examined as previously described (42).

Deformability measurements (osmotic gradient ektacytometry). Whole cell deformability was measured in the ektacytometer (4) as a continuous function of the suspending medium osmolality (12). Cell deformability is expressed as EI which is equivalent to the ellipticity of the deforming cells. The EI was measured during progressive variation of the osmolality from 60 to 450 mosm $\mathrm{kg}^{-1}$ at $22^{\circ} \mathrm{C}$. Each patient erythrocyte deformability measurement was compared with that of a normal control.

Preparation of the erythrocyte membranes. Blood samples were centrifuged and the buffy coat was removed. Erythrocytes were washed twice in $5 \mathrm{mM} \mathrm{NaPO}_{4}, 150 \mathrm{mM} \mathrm{NaCl}$, pH 8.0. Ghosts were prepared according to Dodge et al. (9) except that the lysis buffer was $5 \mathrm{mM} \mathrm{NaPO}_{4}, 0.3 \mathrm{mM}$ PMSF, pH 8.0.

SDS-polyacrylamide gel electrophoresis. Slab gel electrophoresis of ghosts was performed according to Laemmli (18) using a $5-15 \%$ polyacrylamide gradient gel.

Spectrin extraction. For low ionic strength extraction, erythrocyte ghosts were washed twice in $0.3 \mathrm{mM} \mathrm{NaPO}_{4}, \mathrm{pH} 8.0$. The packed membranes were then suspended in an equal volume of low ionic strength buffer containing $0.3 \mathrm{mM} \mathrm{NaPO}_{4}, 0.1 \mathrm{mM}$ EDTA, 0.1 mM PMSF, $0.1 \mathrm{mM} \beta \mathrm{ME}, \mathrm{pH} 8.0$, and either incubated at $37^{\circ} \mathrm{C}$ for $30 \mathrm{~min}$ and immediately cooled on ice $\left(37^{\circ} \mathrm{C}\right.$ extract) or dialyzed overnight at $4^{\circ} \mathrm{C}$ against the same buffer $\left(4^{\circ} \mathrm{C}\right.$ extract). Supernatant extract and ghost residues were separated by centrifugation at $150,000 \times g$ for $45 \mathrm{~min}$.

Study of spectrin dimer-dimer association in solution and determination of equilibrium constant $K_{a}$. The supernatant containing crude spectrin $\left(37^{\circ} \mathrm{C}\right.$ extract) was dialyzed overnight at $4^{\circ} \mathrm{C}$ against 100 volumes of $5 \mathrm{mM} \mathrm{NaPO}_{4}, 0.3 \mathrm{mM}$ PMSF, 150 $\mathrm{mM} \mathrm{NaCl}, 0.1 \mathrm{mM}$ EDTA, $0.2 \mathrm{mM} \beta \mathrm{ME}, \mathrm{pH}$ 8.0. After estimation of the protein concentration by absorbance at $280 \mathrm{~nm}$, taking an $E_{\mathrm{cm}}^{1 \%}(280 \mathrm{~nm})$ of 10.7 (15) and adjustment of required concentrations, each sample of dialyzed proteins was incubated for $240 \mathrm{~min}$ at $30^{\circ} \mathrm{C}$ to induce spectrin dimer to tetramer transformation. After cooling each incubated sample (mean volume, $0.5 \mathrm{ml}$; concentration range, $0.5-2 \mathrm{mg} / \mathrm{ml}$ ) was applied to a $10-$ $30 \%$ (w/v of dialysis buffer) linear sucrose gradient. Ultracentrifugation was performed in a SW 40 Beckman rotor at 40,000 $\mathrm{rpm}$ for $15 \mathrm{~h}$ at $4^{\circ} \mathrm{C}$. Gradients were eluted at $4^{\circ} \mathrm{C}$ from the top to the bottom and the absorbance was automatically monitored at $280 \mathrm{~nm}$. Fraction $\alpha$ of spectrin converted into tetramer after 240 -min incubation at $30^{\circ} \mathrm{C}$ was determined from the sedimentation profile by measuring the areas under the peaks corresponding to spectrin dimer $(D)$ and tetramer $(T)$. $\alpha$ is given by the ratio $(T / D+T)$; writing $c$ for the total molar concentration of spectrin (expressed as a dimer of molecular weight 460,000) $K_{a}$ is given by $\alpha / 2 c(1-\alpha)^{2}$

Distribution of spectrin species in the $4^{\circ} \mathrm{C}$ extract. The distribution of spectrin species in the $4^{\circ} \mathrm{C}$ extract was studied using two methods: (i) the supernatant containing crude spectrin $\left(4^{\circ} \mathrm{C}\right.$ extract) was dialyzed at $4^{\circ} \mathrm{C}$ against 100 volumes of $5 \mathrm{mM}$ $\mathrm{NaPO}_{4}, 0.3 \mathrm{mM}$ PMSF, $150 \mathrm{mM} \mathrm{NaCl}, 0.1 \mathrm{mM}$ EDTA, 0.1 $\mathrm{mM} \beta \mathrm{ME}, \mathrm{pH}$ 8.0. Samples were submitted to sucrose gradient velocity sedimentation and fractions of spectrin dimer and tetramer were estimated from the sedimentation profile as described above; (ii) spectrin species contained in the $4^{\circ} \mathrm{C}$ extracts were 
separated by NDGE. NDGE was performed using $140 \times 100 \times$ $1.5 \mathrm{~mm}$ slab gel with $3.5 \%$ acrylamide in $40 \mathrm{mM}$ Tris, $20 \mathrm{mM}$ sodium acetate, 2 mM EDTA, $10 \%$ glycerol, pH 7.4 (5). Samples were applied to the gel in a buffer containing $10 \mathrm{mM}$ Tris, $1 \mathrm{mM}$ EDTA, $10 \%$ glycerol, $0.005 \%$ bromophenol blue, $\mathrm{pH}$ 8.0. Gels were loaded and electrophoresed at $4^{\circ} \mathrm{C}$ for $48 \mathrm{~h}$ employing 50 V. Gels were stained by Coomassie blue (5) and scanned at 550 $\mathrm{nm}$ in a DU8 Beckman spectrophotometer with a gel scanner system. The proportion of spectrin dimer was estimated by measuring the ratio $D / D+T, D$ and $T$ corresponding respectively to the surface of dimer and tetramer peaks.

Limited tryptic digestion. Two preparations of spectrin were submitted to tryptic digestion: the $37^{\circ} \mathrm{C}$ spectrin extract (adjusted to $0.5 \mathrm{mg} / \mathrm{ml}$ ) and pure spectrin dimer (adjusted to $0.1 \mathrm{mg} / \mathrm{ml}$ ); dimer was separated from tetramer by sucrose gradient sedimentation after the spectrin dimer self-association procedure. Limited tryptic digestions were performed with TPCK-trypsin at $0^{\circ} \mathrm{C}$ for $20 \mathrm{~h}$ in PBS, pH 8.0, with an enzyme/substrate ratio of 1:100 (w/w). Digestions were ended by adding diisopropyl fluorophosphate (final concentration, $1 \mathrm{mM}$ ). Digests were electrophoresed on a $7-22 \%$ SDS-polyacrylamide gradient slab gel (18) with a $3 \%$ stacking gel. Dimensions of the gels were $150 \times 135 \times 1.5$ $\mathrm{mm}$. Gels were run at $100 \mathrm{~V}$ until the dye reached the bottom line, then stained by silver (29) and scanned either through the white light beam provided by the spectrophotometer or at 633 $\mathrm{nm}$. For each experiment, normal control spectrin was digested and electrophoresed in the same conditions as the patient's spectrin.

\section{RESULTS}

Hematological investigations (Table 1). Erythrocyte indices of the five studied family members were obtained at the time of the biochemical investigation.

Morphological studies revealed the presence of ovalocytic cells. On dried blood smears, the mother showed moderate anisocytosis; the father exhibited more prominent anisocytosis with the presence of $2-3 \%$ elliptic cells. On a glutaraldehyde-fixed wet smear preparation, both parents (Fig. 1, $B$ and $C$ ) exhibited the presence of 30 to $40 \%$ ovalocytic or "roundish" cells as defined by Lipton (22). Sister Rab. T. red cell morphology was similar to that of her father Abd. T. (Fig. $1 E$ ).

Morphological studies in proband Mam. T. were more difficult to interpret because of the presence of transfused cells (the study was done 7 weeks after a transfusion). Two cell populations were observed on wet preparation (Fig. $1 A$ ). One population was normocytic and mostly discocytic. The other (estimated at 20\%) was microcytic and composed of microspherocytes and microovalocytes. The normocytic population corresponded probably to the transfused red cells but a careful examination revealed that about $10 \%$ of the cells were slightly ovalocytic and similar to those observed in both parents.

A blood sample from the sister Mag. T. was collected at the 3rd day of life; wet preparations (Fig. $1 F$ ) showed anisocytosis, poikilocytosis, and numerous stomatocytes (premature infant). Careful examination revealed the presence of few schizocytes, ovalocytes, and elliptocytes.

Erythrocyte morphology in brother Han. T. was normal on both dried and wet preparation (Fig. 1D).

Osmotic gradient ektacytometry revealed abnormal cell deformability. Both parents (Fig. 2), sister Rab. T., and sister Mag. T. (Fig. 3) had red cells less deformable than control red cells. EI was decreased in isotonic conditions. EI improved steadily when cells were in moderate hypotonic conditions but the optimum EI was always lower than that of the control. The minimal EI values (determined in extreme hypotonic and hypertonic conditions) were obtained at the same osmolalities as controls.

In proband Mam. T., EI in isotonic conditions was decreased (Fig. 2); no steady increase of EI was observed in moderate hypotonic conditions. As shown in Fig. 3, brother Han. T. red cell deformability was normal and similar to control.
Table 1. Hematological investigations*

\begin{tabular}{lccccc}
\hline & $\begin{array}{c}\text { Birth } \\
\text { date }\end{array}$ & $\begin{array}{c}\mathrm{Hb} \\
(\mathrm{g} / \mathrm{dl})\end{array}$ & $\begin{array}{c}\text { Red cell } \\
\text { count } \\
\left(\times 10^{12} / \text { liter }\right)\end{array}$ & $\begin{array}{c}\text { Mean cell } \\
\text { volume } \\
(\mathrm{fl})\end{array}$ & $\begin{array}{c}\text { Reticu- } \\
\text { locytes } \\
(\%)\end{array}$ \\
\hline Mother Men. T. & 1959 & 13.3 & 4.53 & 87 & 1 \\
Father Abd. T. & 1948 & 15.9 & 5.63 & 82 & 0.9 \\
Brother Han. T. & 1979 & 12 & 4.2 & 82 & 1.4 \\
Sister Rab. T. & 1980 & 11 & 3.9 & 83 & 1.8 \\
Proband Mam. T. & 1981 & 9 & 3.3 & 75 & 0.3 \\
\hline
\end{tabular}

* Erythrocyte indices of the proband Mam. T. were obtained 7 weeks after a transfusion.
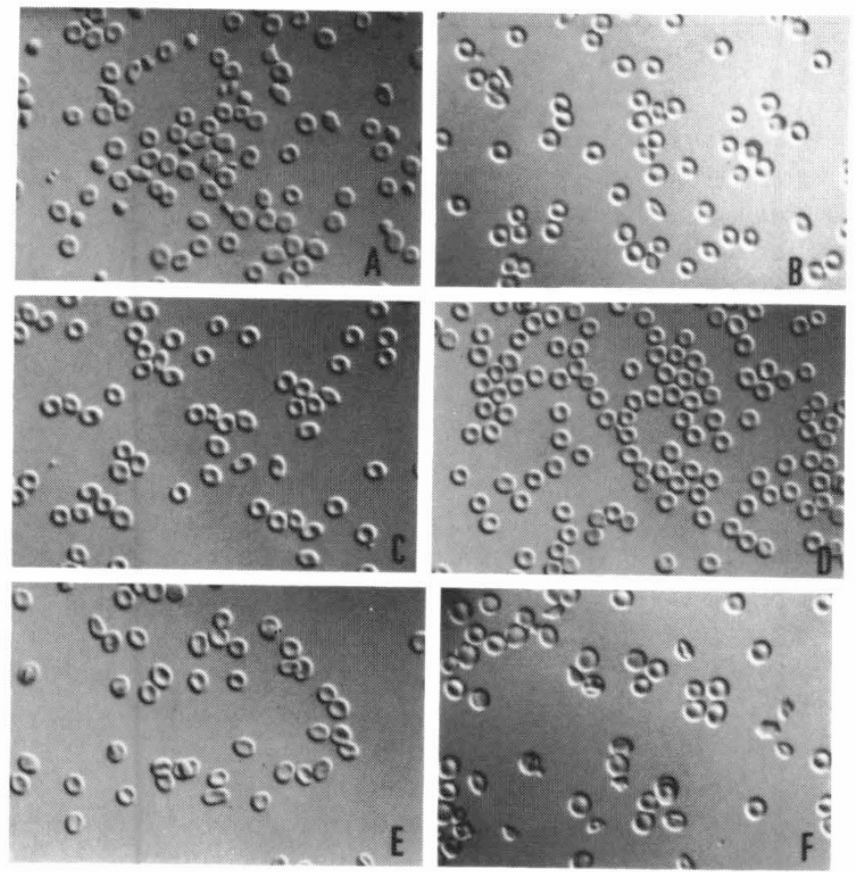

Fig. 1. Study of erythrocyte morphology. Erythrocytes were examined on glutaraldehyde-fixed wet smear preparations by light phase contrast microscopy $(\times 500)$. A, proband Man. T.; $B$, father Abd. T.; $C$, mother Men. T.; $D$, brother Han. T.; $E$, sister Rab. T.; $F$, sister Mag. T.

Erythrocyte thermal sensitivity. Thermal sensitivity was found normal in both parents, brother Han. T., and sister Rab. T. In the proband, no fragmentation was observed until $49^{\circ} \mathrm{C}$ but this study could not be conclusive because of the small percentage of abnormal erythrocytes present in the red cell population.

SDS-polyacrylamide gel electrophoresis patterns (Fig. 4). Erythrocyte membrane electrophoresis of the five family members exhibited normal patterns.

Spectrin dimer-dimer association was decreased both in membrane and in solution. In the $4^{\circ} \mathrm{C}$ extract, the spectrin dimertetramer equilibrium is kinetically trapped in its native state in the membrane. In normal subjects, the tetrameric state is largely predominant. The normal percentage of spectrin dimer, determined by means of sucrose gradient velocity centrifugation was found to be $15 \pm 2 \%(n=24)$. Similar values were obtained using NDGE: $18 \pm 4 \%(n=15)$.

Table 2 shows the percentage of spectrin dimer in the $4^{\circ} \mathrm{C}$ extract found in the five studied family members using sucrose gradient velocity sedimentation. Moderate but significant increase of spectrin dimer was found in proband. Both parents and sister Rab. T. exhibited greater amounts of spectrin dimer (values between 45 and $48 \%$ ). The percentage of spectrin dimer was also determined twice in mother Men. T. using NDGE. The mean value was $45 \%$ which is similar to that obtained using sucrose gradient separation.

As reported $(8,26)$, conversion of spectrin dimer into tetramer can be directly studied in the $37^{\circ} \mathrm{C}$ extract. After incubation at 


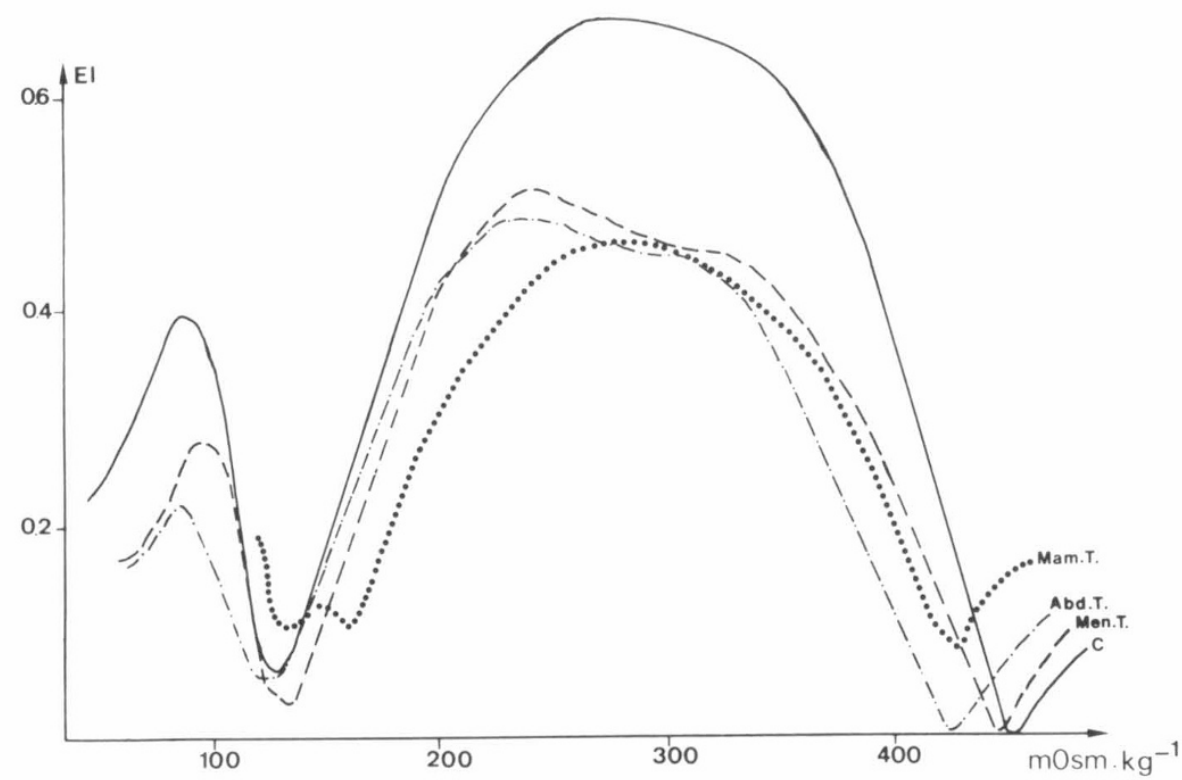

Fig. 2. Osmotic gradient ektacytometry. Curves of both parents (Abd. T. and Men.T.) are compared to control $C$.

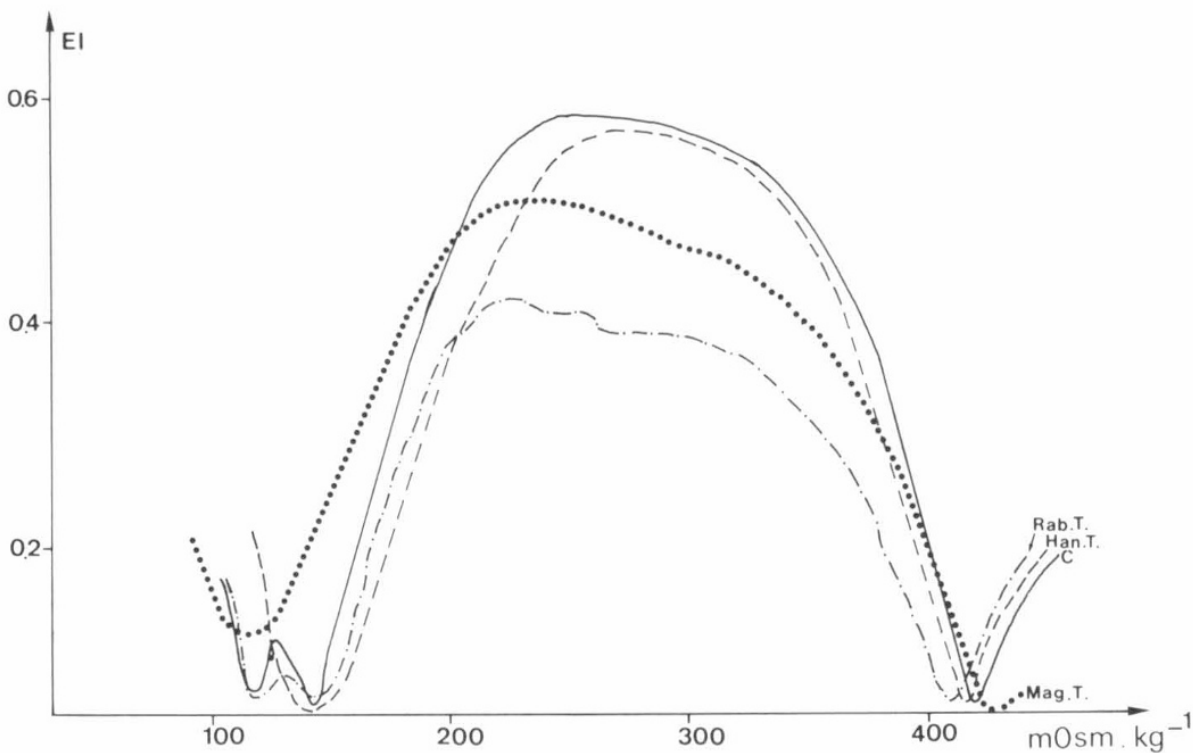

Fig. 3. Osmotic gradient ektacytometry. Curves of sister Rab. T., brother Han. T., and sister Mag. T. are compared to control $C$.

$30^{\circ} \mathrm{C}$ for $240 \mathrm{~min}$ in order to reach the equilibrium state, we found the association constant $\left(K_{a}\right)$ for normal spectrin to be 6 $(+0.4) \times 10^{5} \mathrm{M}^{-1}(n=42) . K_{a}$ values, determined in each member of the family are presented in Table 2 . Spectrin dimer self-association was defective in both parents, sister Rab. T., and proband Mam. T.

Limited tryptic digestion of spectrin from normal subjects. As proposed by Lawler et al. (19), an enzyme/substrate ratio of 1:100 was chosen to investigate both control and patient spectrin. The crude $37^{\circ} \mathrm{C}$ extracts were extensively used as substrate because peptide patterns obtained either from $37^{\circ} \mathrm{C}$ extracts or gel filtration purified spectrin were quite similar. Peptide patterns produced by limited tryptic digestion of spectrin in 23 white and 31 black normal subjects (native of Africa or Antilles) were reproducible and no variations were observed in the 70,000- to 110,000-dalton peptide range. However, some variations were noticed in 35,000-, 37,000-, 40,000-, and 48,000-dalton peptides as previously described (19).

Limited tryptic digestion of spectrin from the five family members. Results are summarized in Table 2. Two different preparations of spectrin were subjected to tryptic digestion: crude spectrin extracted at $37^{\circ} \mathrm{C}$ and spectrin dimer separated from tetramer after the spectrin dimer self-association procedure.

Tryptic digest patterns of the $37^{\circ} \mathrm{C}$ extracts. As shown in Fig. 5 , densitometric tracings of both parental tryptic digest patterns revealed a decrease in the 80,000 -dalton peptide, an increase in a 78,500-dalton peptide, and a broadening of a 74,000-dalton peptide. Densitometric tracing of the proband's pattern (Fig. 6) displayed the same findings but to a lesser extent. Furthermore, a 28,000-dalton peptide was markedly reduced in both parents (Fig. 7A). The other modifications in the 35,000- to 48,000dalton peptides range are shown in Table 2.

Tryptic digest patterns of isolated spectrin dimer. As shown in Fig. 7, $B$ and $C$, the spectrum of spectrin dimer tryptic digests was different from that obtained with the $37^{\circ} \mathrm{C}$ extract: a larger quantity of material associated with the high molecular weight peptides was present. The discrepancy could be explained by the five times lower concentration of protein used in the digestion procedure and the presence of sucrose in the dimer sample (about $20 \%, w / v$ ). In both parents (Fig. 7, $B$ and $C$ ), the decrease in the 80,000 -dalton peptide and increase in the 74,000-dalton peptide were more manifest than in the $37^{\circ} \mathrm{C}$ extract tryptic patterns. 

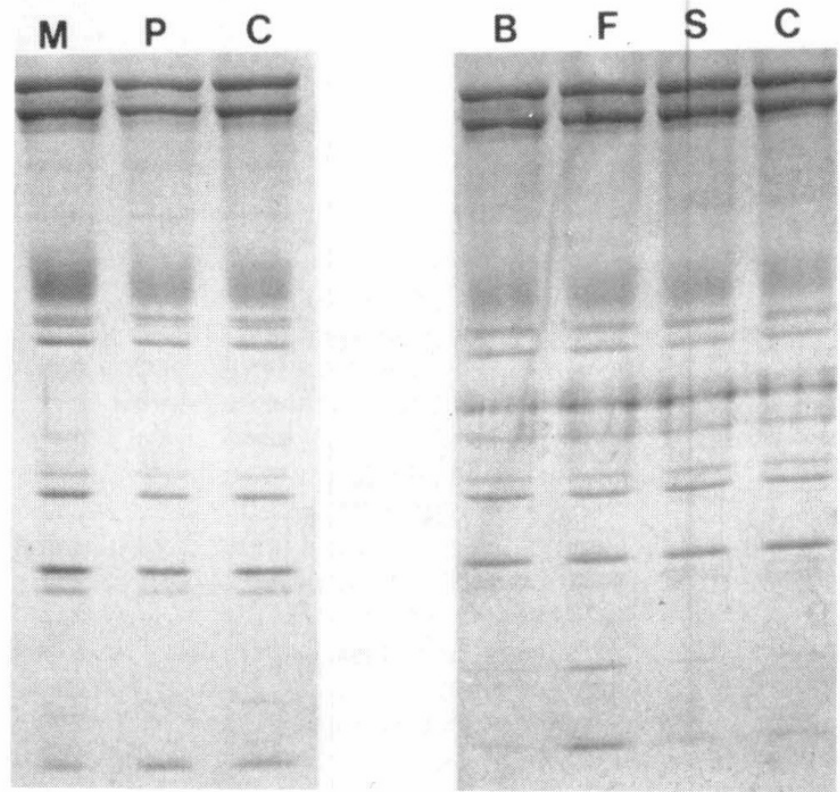

Fig. 4. SDS-polyacrylamide gel electrophoresis. $M$, mother Men. T.; $P$, proband Mam. T.; $B$, brother Han. T.; $F$, father Abd. T.; $S$, sister Rab. T.; $C$, control.
The decrease in the 28,000-dalton peptide was more apparent in the mother (Fig. 7C). The tryptic pattern of sister Rab. T. (Fig. $7 B$ ) was indistinguishable from that of her father and the tryptic pattern of normal brother Han. T. (Fig. 7, $B$ and $C$ ) did not show any modifications in the 80,000-, 74,000-, and 28,000dalton peptides. The other modifications in the 35,000- to 50,000-dalton peptides range are shown in Table 2 .

\section{DISCUSSION}

The case reported herein illustrates the difficulty of neonatal hemolysis diagnosis in a transfusion-dependent infant. The presence of poikilocytes in blood leads one to search for a red cell membrane skeleton defect. Owing to recent additions to knowledge of the erythrocyte membrane, it is now possible to approach the diagnosis by means of biochemical evaluations of both parents, even if they are asymptomatic. So the first time discovery of a spectrin self-association defect in both parents allowed us to suspect double inheritance of this abnormality in the proband. A complete evaluation of the family confirmed our hypothesis. The moderate increase of spectrin dimer in the proband $4^{\circ} \mathrm{C}$ extract $(26 \%)$ compared to the values found in other family members could be explained by the presence in the blood of transfused cells. Until today, three congenital hemolytic disorders with poikilocytosis have been found to be related to a defective self-association of spectrin: $\operatorname{HPP}(8,17,20,26)$, homozygous HE

Table 2. Biochemical investigations*

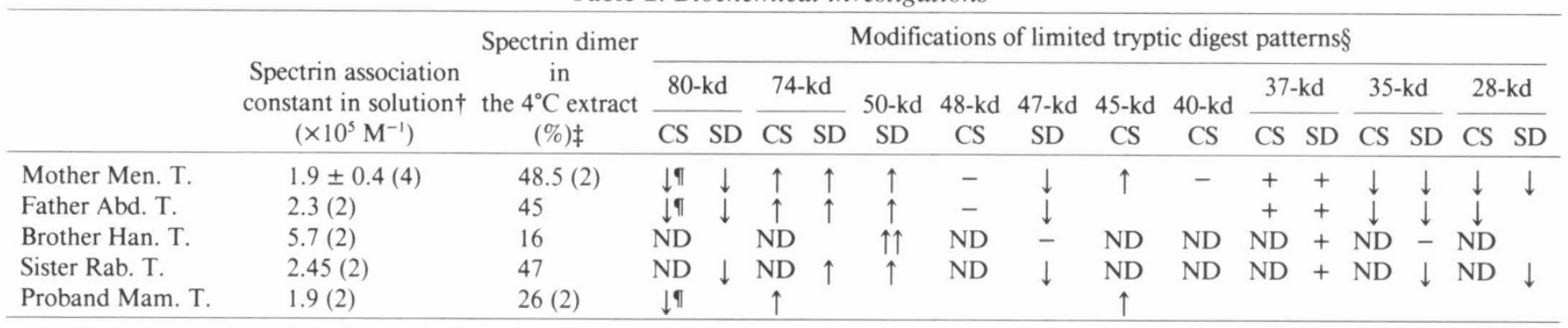

* Only unequivocal modifications of proband's spectrin tryptic pattern noticed in the $37^{\circ} \mathrm{C}$ extract digest are presented. Numbers in parentheses, number of samples.

$\dagger$ Normal values are $6 \pm 0.4 \times 10^{5} \mathrm{M}^{-1}$.

$\ddagger$ Normal values are $15 \pm 2 \%$.

$\S \mathrm{CS}$, crude spectrin extract performed at $37^{\circ} \mathrm{C}$. SD, spectrin dimer isolated from spectrin tetramer after self-association process. ND, not done. + and - correspond respectively to the appearance and disappearance of the peptide. $\uparrow$ and $\downarrow$ correspond respectively to the increase and decrease in the peptide amount.

I The decrease in the 80,000 -dalton peptide was concomitant with increase in a 78,500-dalton peptide.

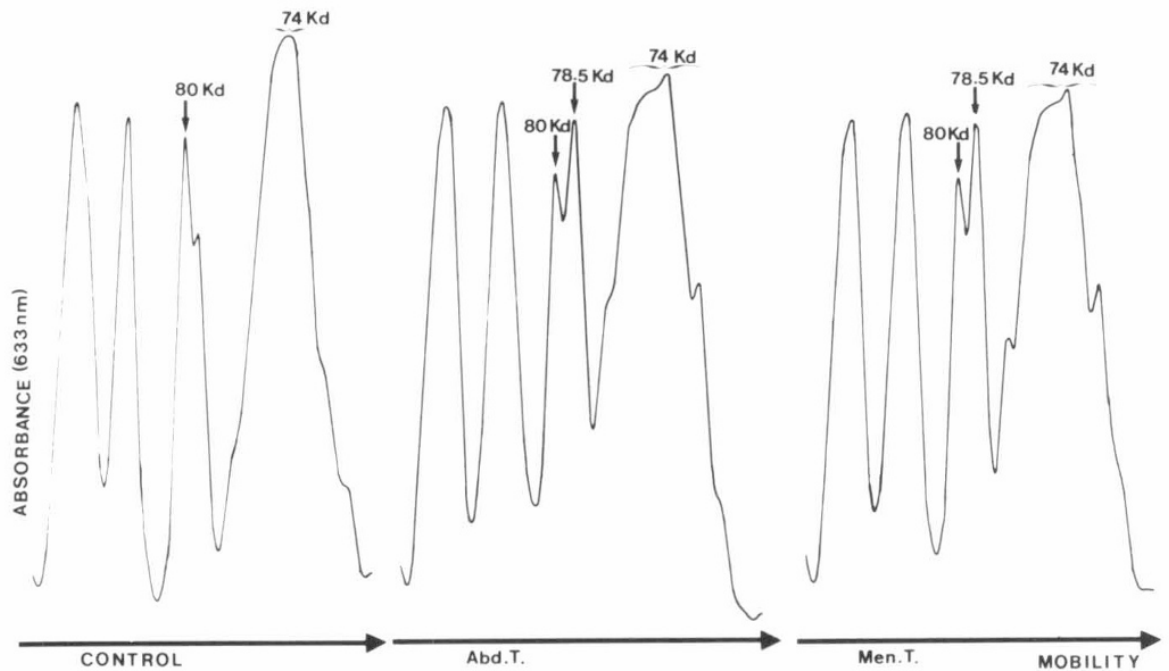

Fig. 5. Tryptic digest pattern densitometric tracings restricted to the 70,000-110,000-dalton region, of both parents Abd. T. and Men. T. and control. 
(10), and HE with pyknocytosis in infants (33; personal observation); the latter disease is not consistent with the clinical features of our case because severe hemolysis and poikilocytosis persisted after 18 months (34). Blood smears in $\operatorname{HPP}(8,26,34$,
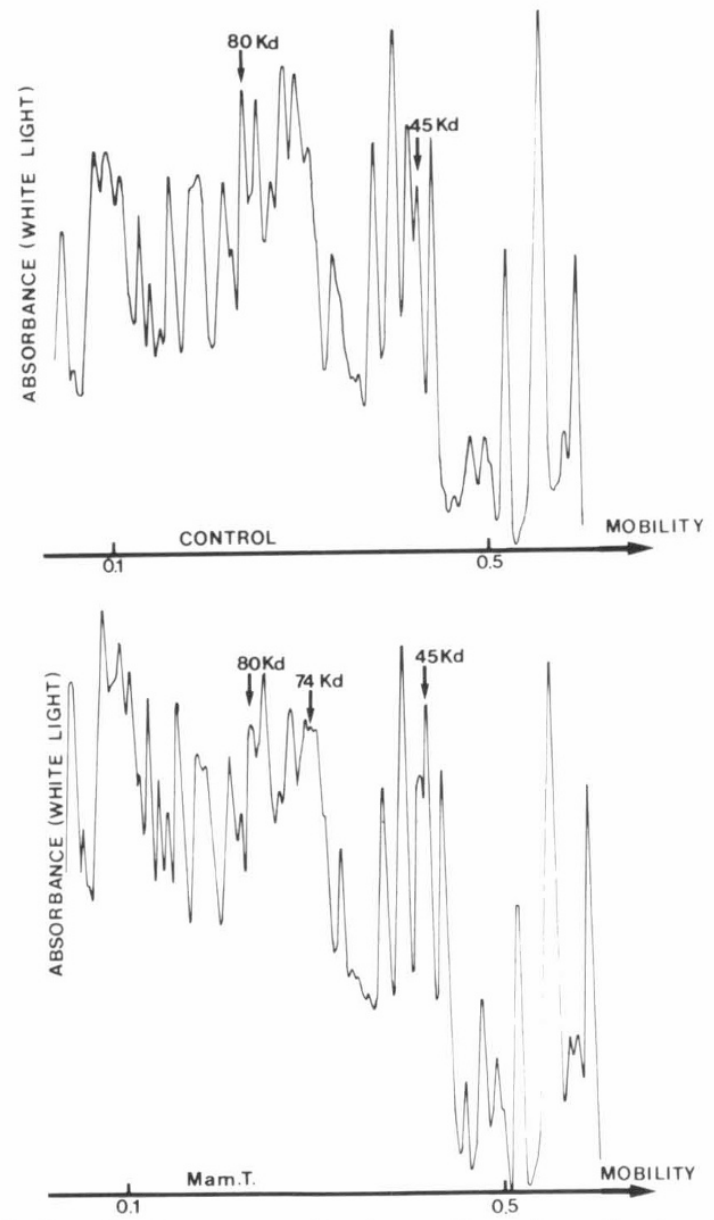

Fig. 6. Tryptic digest pattern densitometric tracings of proband Men. T. and control.
42) and homozygous $\mathrm{HE}(10,13,22,32,35,41)$ are quite similar, characterized by extreme poikilocytosis, with fragments, budding cells, microspherocytes, microelliptocytes, and other bizarre poikilocytes. Notwithstanding the presence of transfused cells in the proband we studied, it was possible to recognize a poikilocytic population.

Degree of elliptocytosis may be artifactually diminished in dried smears (27) and, as illustrated in our studies, it is useful to examine glutaraldehyde-fixed wet smear preparations. By this technique, we depicted ovalocytic cells in both parents, two sisters, and the proband. The few elliptocytes shown in the father's smear could be related to the thalassemia trait. Many authors have previously noticed that, in some HE, the cells may be only slightly eccentric and not readily appreciated as abnormal $(2,40,41)$. Ektacytometric studies were determinant in this field. Osmotic gradient ektacytometry curves obtained in both parents and two sisters were similar and the general aspect of the curves was consistent with hereditary elliptocytosis. In our experience, this characteristic profile, with a steady increase of the EI in moderate hypotonic conditions, was only found in HE. It was never observed in hematological disorders such as iron deficiency, thalassemia trait, or megaloblastic anemia where anisocytosis with few ovalocytes or elliptocytes could be present.

The low reticulocyte count found in the proband (Table 1) cannot be totally explained by transfusion frequency. Bone marrow studies did not show any maturation defect or red cell aplasia. Anomalously low reticulocyte counts with erythroblastic hyperplasia were previously reported by Torlontano et al. (38) in some cases of hereditary hemolytic ovalocytosis. On the basis of the studies reported by Prchal et al. (34) the youngest erythrocyte population could display increased fragility providing an explanation for the observed low reticulocyte count.

Among tryptic digestion pattern modifications observed in this family, only decrease in the 80,000 -dalton peptide and increase in the 74,000-dalton peptide were related to the defective selfassociation of spectrin. The decrease in the 28,000-dalton peptide, more clearly observed in the $37^{\circ} \mathrm{C}$ extract digests, also correlated with the spectrin defect. These tryptic digest abnormalities were more readily visualized in the spectrin dimer fraction remaining after dimer to tetramer conversion. This emphasizes the relationship between tryptic pattern modifications and functional spectrin abnormality, since the defective

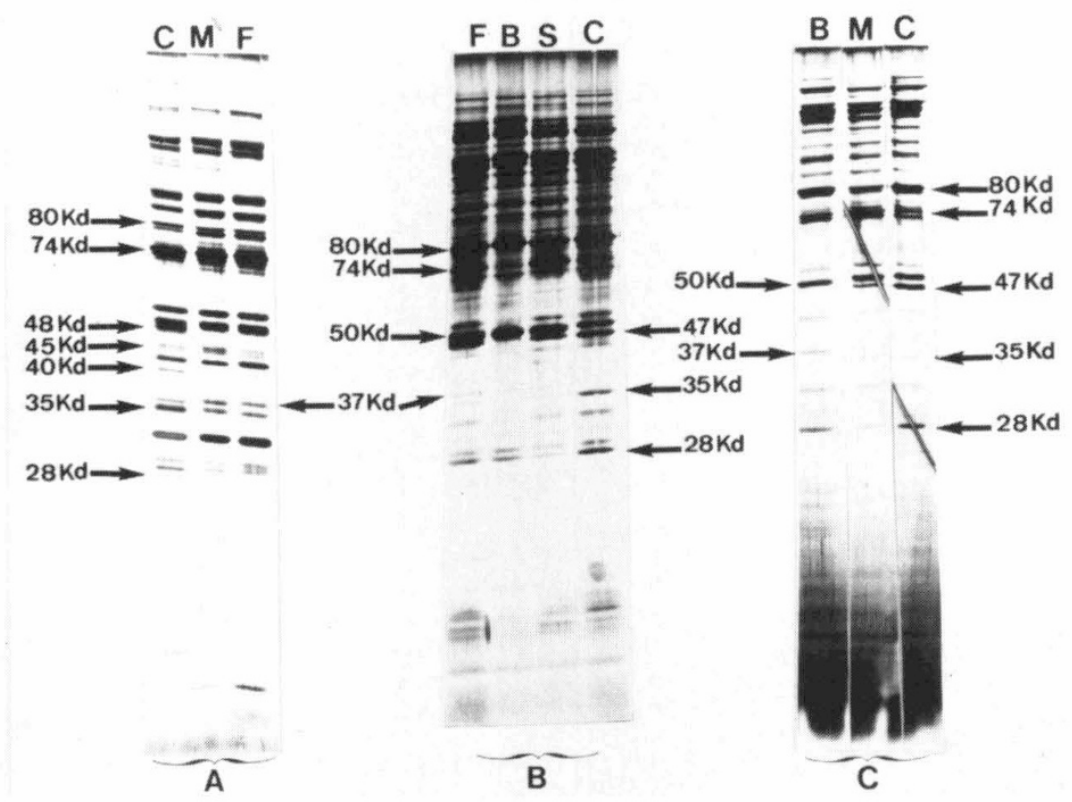

Fig. 7. SDS-polyacrylamide gel electrophoresis patterns of limited tryptic digests. The separating gel was a $7-22 \%$ gradient; $10 \mu \mathrm{g}$ of protein were loaded per lane. Peptides bands were stained by silver $A$, crude spectrin $\left(37^{\circ} \mathrm{C}\right.$ extract) tryptic digests of mother Men. T. $(M)$, father Abd. T. $(F)$, and control $(C) . B$ and $C$, isolated spectrin dimer tryptic digests of both parents, brother Han. T. $(B)$ and sister Rab. T. $(S)$. 
spectrin molecule remained mostly in dimeric form. Morrow et al. (31) showed that the 80,000-dalton peptide fragment, called $\alpha \mathrm{I}$ domain resulting from limited tryptic digestion of spectrin, corresponds to the terminal fragment of the $\alpha$ chain involved in the self-association process. Furthermore, Morrow et al. have also demonstrated (30) that trypsin is capable of removing a 6,000-dalton peptide from the 80,000 -dalton peptide and the resulting 74,000-dalton peptide has lost the ability to bind the native spectrin dimer. So, the defective spectrin self-association is consistent with the modification of the 80,000- and 74,000dalton peptides. Identical results have been previously reported by Lawler et al. in the two HPP kindred (19) and by Liu et al. in some type I HE cases (23). As proposed by Lawler, we could infer that the conformational change of the spectrin molecule, affecting the self-association site of the $\alpha$ I domain renders it more susceptible to tryptic digestion.

Other tryptic pattern modifications, nonrelated to the functional spectrin abnormality, were also noticed (Table 2). Study of family $\mathrm{T}$. allowed us to consider that the presence of both the 37,000- and 35,000-dalton peptides corresponds to a heterozygous state of a genetic polymorphism, previously depicted using Cleveland digest of $\alpha$ chain (21). The 37,000-dalton peptide, found in brother Han. T. corresponds to the homozygous state. The variations of the 47,000- and the 50,000-dalton peptides paralleled those of the 35,000- and 37,000-dalton peptides. Recently, Knowles et al. (16) showed that the digestion of the spectrin $\alpha$ II domain generates 46,000- and 35,000-dalton peptides which probably correspond to our 45,000- and 35,000dalton peptides. The authors also described $\alpha$ II domain variations in a black population identical to those described in family $\mathrm{T}$.

We think that it is reasonable to propound the diagnosis of heterozygous type I HE for both parents and two sisters and the diagnosis of homozygous type I HE for the proband (Fig. 8) owing to the following reasons: slight ovalocytosis was present in both parents and two sisters; cell deformability ektacytometric studies gave the same profiles of curve as those observed in patients with HE; defective spectrin dimer self-association was found in both parents, sister Rab. T., and proband associated with the same abnormal spectrin digest pattern. Nevertheless, each of the above data is not conclusive and has to be discussed. Elliptocytes were slightly eccentric and only appreciated on wet smear preparations. Ektacytometric studies confirmed the presence in these patients of a red cell population exhibiting the abnormal deformability characteristic of that observed in $\mathrm{HE}$, but this syllogism might be found to be erroneous in the future. Clinical presentation of the proband is consistent either with HPP or with homozygous HE. Erythrocyte thermal sensitivity studies in the proband cannot be conclusive because of the presence of transfused cells. In HPP kindred reported by Lawler et al. (19), spectrin abnormalities identical to those we described were found only in one of the two parents (HPP carriers). However, Mentzer et al. (28) reported recently HPP kindred in which a spectrin dimer excess in the $4^{\circ} \mathrm{C}$ extracts was found in both parents, one of whom also exhibited elliptocytosis. In addition, the structural alterations of the spectrin molecule pep-

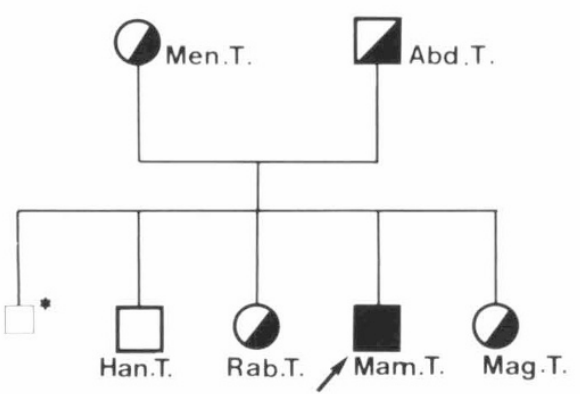

Fig. 8. Pedigree of T. family. $\boldsymbol{\square}$, heterozygous elliptocytosis; homozygous elliptocytosis; $\star$, stillborn; $\nearrow$, proband. tide mapping found in the family $\mathrm{T}$. has been described in HPP as well as in some cases of type I HE.

Clinical, rheological, and biochemical investigations have to be carried on in an attempt to understand better the relationship between HE and HPP. It remains that the erythrocyte membrane biochemistry has already established itself as a permanent companion in diagnosis of many congenital hemolytic disorders.

Acknowledgments. We thank Dr. M. Vroclans for HLA typing. The photographic work was done by A. De Boisfleury and the manuscript was prepared by N. Lemaire.

\section{REFERENCES}

1. Agre P, Orringer EP, Chui OH, Bennett V 1981 A molecular defect in two families with hemolytic poikilocytic anemia. Reduction of high affinity membrane binding sites for ankyrin. J Clin Invest 68:1566

2. Austin RF, Desforges JF 1969 Hereditary elliptocytosis: an unusual presentation of hemolysis in the newborn associated with transient morphologic abnormalities. Pediatrics 44:196

3. Bennett V 1982 The molecular basis for membrane-cytoskeleton association in human erythrocyte. J Cell Biochem 18:49

4. Bessis M, Mohandas N 1974 Mesure continue de la déformabilité cellulaire par une méthode diffractométrique. CR Acad Sci Paris 278:3263

5. Burke BE 1981 Structural studies of human erythrocyte spectrin. PhD thesis, University of London

6. Coetzer T, Zail S 1982 Spectrin tetramer-dimer equilibrium in hereditary elliptocytosis. Blood 59:900

7. Cohen CM 1983 The molecular organization of the red cell membrane skeleton. Semin Hematol 20:141

8. Dhermy D, Féo C, Garbarz M, Bournier O, Dommergues JP, Garcia J, Boivin P. Tchernia G 1983 Anémie hémolytique congénitale par instabilité thermique érythrocyctaire et défaut de tétramérisation de la spectrine. Etude de la déformabilité érythrocytaire d'un nouveau cas de pyropoikilocytose héréditaire par visco-diffractométrie. Nouv Rev Fr Hématol 25:7

9. Dodge JT, Mitchell C, Hanahan DJ 1963 The preparation and chemical characteristics of hemoglobin free ghosts of human erythrocyte. Arch Biochem Biophys 100:119

10. Evans JPM, Baines AJ, Hann IM, Al-Hakim I, Knowles SM, Hoffrand AV 1983 Defective spectrin dimer-dimer association in a family with transfusion dependent homozygous hereditary elliptocytosis. Br J Haematol 54:163

11. Féo CJ, Fischer S, Piau JP, Grange MG. Tchernia G 1980 Première observation de l'absence d'une protéine de la membrane érythrocytaire (bande 4.1) dans un cas d'anémie elliptocytaire familiale. Nouv Rev Fr Hématol 22:315

12. Féo CJ, Nossal M, Jones E, Bessis 1982 Une nouvelle technique d'étude de la physiologie des globules rouges: la mesure de leur déformabilité en fonction de l'osmolalité. Résultats obtenus par un ektacytomètre automatisé sur le sang normal et dans différentes anémies hémolytiques. CR Acad Sci Paris 295:687

13. Grech JL, Cachia EA, Calleja F, Pullicino F 1961 Hereditary elliptocytosis in two Maltese families. J Clin Pathol 14:365

14. Gretillat F, Delepine N, Dhermy D, Féo C, Allaneau C, Desbois JC, Herrault A 1983 Hemolyse néonatale secondaire à une poikilocytose congénitale. N Presse Med 12:2751

15. Kam Z, Josephs R. Eisenberg H, Gratzer WB 1977 Structural study of spectrin from human erythrocyte membranes. Biochemistry 16:5568

16. Knowles W, Marchesi SL, Marchesi VT 1983 Spectrin: structure, function and abnormalities. Semin Hematol 20:159

17. Knowles WJ, Morrow JS, Speicher DW, Zarkowsky HS, Mohandas N, Mentzer WC, Shohet SB, Marchesi VT 1983 Molecular and functional changes in spectrin from patients with hereditary pyropoikilocytosis. J Clin Invest $71: 1867$

18. Laemmli UK 1970 Cleavage of structural proteins during the assembly of the head of the bacteriophage T4. Nature 227:680

19. Lawler J, Liu SC, Palek J, Prchal J 1982 Molecular defect of spectrin in hereditary pyropoikilocytosis. Alterations in the trypsin-resistant domain involved in spectrin self-association. J Clin Invest 70:1019

20. Lawler J, Palek J, Liu SC, Prchal J,, Butler WM 1982 Heterogeneity in the molecular defect of spectrin in hereditary pyropoikilocytosis. Blood 60:37a (Suppl 1, abstr)

21. Lecomte MC, Gautero H, Boivin P 1983 Polymorphisme génétique de la chaine alpha de la spectrine. CR Acad Sci Paris 296:841

22. Lipton EL 1955 Elliptocytosis with hemolytic anemia: the effects of splenectomy. Pediatrics 15:67

23. Liu SC, Lawler J, Prchal J, Palek 1981 Defective dimer-dimer association and altered tryptic digestion of spectrin in variants of hereditary elliptocytosis. Blood 58:45a (Suppl 1, abstr)

24. Liu SC, Palek J 1980 Spectrin tetramer-dimer equilibrium and the stability of erythrocyte membrane skeletons. Nature 285:586

25. Liu SC, Palek J, Prchal JT 1982 Defective spectrin dimer-dimer association in hereditary elliptocytosis. Proc Natl Acad Sci USA 79:2072

26. Liu SC, Palek J, Prchal J, Castleberry RP 1981 Altered spectrin dimer-dimer association and instability of erythrocyte membrane skeletons in hereditary pyropoikilocytosis. J Clin Invest 68:597

27. Lux SA, Glader BE 1981 Disorder of the red cell membrane. In: Nathan DG, 
Oski, FA (eds) Hematology of Infancy and Childhood, 2nd ed. WB Saunders Company, London, p. 513

28. Mentzer WC, Turetsky T, Mohandas N, Koenig H, Schrier S 1982 Identification of the hereditary pyropoikilocytosis (HPP) carrier state. Blood 60:38a (Suppl 1, abstr)

29. Morrissey DH 1981 Silver stain for proteins in polyacrylamide gels: a modified procedure with enhanced uniform sensitivity. Anal Biochem 117:307

30. Morrow JS, Marchesi VT 1981 Self-assembly of spectrin oligomers in vitro: a basis for a dynamic cytoskeleton. J Cell Biol 88:463

31. Morrow JS, Speicher DW, Knowles WJ, Hsu CJ, Marchesi VT 1980 Identification of functional domains of human erythrocyte spectrin. Proc Natl Acad Sci USA 77:6592

32. Nielsen JA, Strunk KW 1968 Homozygous hereditary elliptocytosis as the cause of haemolytic anemia in infancy. Scand J Haematol 5:486

33. Palek J, Lux SE 1983 Red cell membrane skeletal defects in hereditary and acquired hemolytic anemias. Semin Hematol 20:189

34. Prchal JT, Castleberry RP, Parmley RI, Crist WM, Mulluh A 1982 Hereditary pyropoikilocytosis and elliptocytosis: clinical, laboratory and ultrastructural features in infants and children. Pediatr Res 16:484

35. Pryor DS, Pitney WR 1967 Hereditary elliptocytosis: a report of two families from New Guinea. Br J Haematol 13:126

36. Speicher DW, Morrow JS, Knowles WJ, Marchesi VT 1982 A structural model of human erythrocyte spectrin: alignment of chemical and functional domains. J Biol Chem 257:9093

37. Tchernia G, Mohandas N, Shohet SB 1981 Deficiency of skeletal membrane protein band 4.1 in homozygous hereditary elliptocytosis. Implications for erythrocyte membrane stability. J Clin Invest 68:454

38. Torlontano G, Fioritoni G, Salvati AM 1979 Hereditary haemolytic ovalocytosis with defective erythropoiesis. Br J Haematol 43:435

39. Ungewickell E, Bennett PM, Calvert R, Ohanian V, Gratzer WB 1979 In vitro formation of a complex between cytoskeletal proteins of the human erythrocyte. Nature 80:811

40. Weiss HJ 1963 Hereditary elliptocytosis with hemolytic anemia. Report of six cases. Am J Med 35:455

41. Wyanot H, Bancroft PM, Winship TO 1941 Elliptic erythrocytes in man. Arch Intern Med 68:1043

42. Zarkowsky HS, Mohandas N, Speaker CB, Shohet SB 1975 A congenital haemolytic anaemia with thermal sensitivity of the erythrocyte membrane. Br J Haematol 29:537

\title{
Iron Is Sequestered as Ferritin in Macrophages in Skeletal Muscle of Vitamin E-deficient Rabbits
}

\author{
JEN-YIH CHU, PHITSAMAI KANJANANGGULPAN, ALBERT C. CHOU,' \\ DAPHNE E. DE MELLO, AND COY D. FITCH \\ Departments of Pediatrics, Pathology, and Internal Medicine, St. Louis University School of Medicine, \\ St. Louis, Missouri, 63104
}

\section{Summary}

Weanling rabbits were fed a purified diet with or without vitamin $\mathrm{E}$ supplementation to evaluate the abnormal sequestration of iron in skeletal muscle associated with vitamin $\mathbf{E}$ deficiency. A severe myopathy developed in unsupplemented rabbits within 3 to 4 weeks. At this time, the concentration of soluble nonheme iron in biceps femoris muscles had increased from 2.1 $\pm 0.4 \mu \mathrm{g} / \mathrm{g}$ wet weight (mean $\pm \mathrm{SD}$ ) for six control rabbits to 4.3 \pm 1.4 for 10 vitamin E-deficient rabbits, and total nonheme iron had increased from $5.0 \pm 1.2$ to $8.4 \pm 3.3$. Soleus muscles had even greater increases in total and soluble nonheme iron concentrations. Intramuscular injection of iron-dextran caused large increases in total and soluble nonheme iron in noninjected muscle of vitamin E-deficient rabbits, which further exaggerated the difference between the two groups. By radioimmunoassay using an antibody to rabbit liver ferritin, the concentration of ferritin in biceps femoris muscles increased from $0.47 \pm 0.18 \mu \mathrm{g} / \mathrm{g}$ wet weight for seven control rabbits to $6.34 \pm 1.70$ for 14 vitamin $\mathrm{E}$ -

Received February I, 1984; accepted March 26, 1984.

Requests for reprints should be addressed to Jen-Yih Chu, M.D., Department of Pediatrics, Cardinal Glennon Memorial Hospital for Children, 1465 S. Grand, St. Louis, MO 63104

This research was supported in part by Grant 82-CRCR-1-1114 from the Human Nutrition Program, Science and Education Administration, United States Department of Agriculture and in part by a Biomedical Research Support Grant from the School of Public Health and Tropical Medicine, Tulane University and Fleur de Lis Fund, Cardinal Glennon Memorial Hospital for Children. We wish to thank Judith Baldassare, Mary Ann Collins, Alice Cottrell, and Mary McGlone for their technical help and Merrell Dow Pharmaceuticals, Inc., Cincinnati, for the supply of iron dextran used in this study.

Present address: Department of Nutrition, Tulane University School of Public Health and Tropical Medicine, New Orleans, LA 70112 deficient rabbits. Uptake of intravenously injected transferrinbound iron into muscle of vitamin E-deficient rabbits was not increased in a short term experiment $(6 \mathrm{~h})$, but radioiron did accumulate in muscle in a long term experiment (6 days). There was no trapping of heat-damaged erythrocytes, no phagocytosis of intravenously injected carbon particles, and no erythrophagocytosis in muscle. An immunohistological staining method designed to detect ferritin in tissue sections stained muscle from normal rabbits very scantily but intensely stained macrophages in the muscle of vitamin E-deficient rabbits. We conclude that macrophages in skeletal muscle of vitamin E-deficient rabbits take up iron from transferrin and incorporate it into ferritin, in which form it is relatively unavailable for erythropoiesis because of slow release.

Young vitamin E-deficient rabbits have high serum ironbinding capacity, low serum iron, and high erythrocyte free protoporphyrin concentrations, and they recover slowly from anemia induced by phlebotomy (2). These abnormalities are secondary to iron sequestration in muscle rather than to a decrease in the total amount of iron in the body (2). Since vitamin E-deficiency is known to cause an extensive necrotizing myopathy accompanied by infiltration of macrophages (1), the present study evaluated the involvement of macrophages in the sequestration of iron.

\section{MATERIALS AND METHODS}

Young New Zealand White rabbits initially weighing approximately $650 \mathrm{~g}$ were used in all except one experiment. Rabbits 